\title{
Kajian Analisis Identifikasi Iklan Luar Ruang Wall Painting
}

\author{
Gema Ariprahara
}

Jurusan Desain Komunikasi Visual, Universitas Komputer Indonesia

\begin{abstract}
Abstrak.Iklan luar ruang merupakan alat komunikasi komersial konvensional yang digunakan oleh kebanyakan produsen untuk memberikan informasi dan menancapkan identitas produk pada benak konsumennya. Media yang digunakan umumnya menggunakan papan reklame atau billboard, neon sign, neon box, spanduk, baligo, poster, pamplet dan media luar ruang lainnya. Kepadatan iklan dalam sebuah kota senantiasa dipantau oleh dinas pendapatan dan pertamanan daerah karena dalam penempatannya harus sesuai dengan undang-undang yang berlaku. Perkembangan iklan luar ruang semakin marak dengan hadirnya iklan wall painting yang terletak pada beberapa bangunan kota yang memiliki dinding yang kosong yang dapat dimanfaatkan sebagai objek media iklan. Ruang tersebut umumnya dibiarkan kosong dan hanya berisi warna plain dengan adanya kreativitas pekerja media dinding tersebut dijadikan media iklan. Meski ukurannya besar dan dapat digolongkan sebagai media luar ruang sejenis billboard namun dalam visualisasinya memiliki perbedaan. Visualisasi pada wall painting memiliki keterbatasan karena faktor teknis dan tingkat keterlihatan objek.
\end{abstract}

Penelitian ini lebih melihat mengenai analisa deskripsi iklan wall painting yang terdapat pada ruang publik kota. Fokus analisa terhadap identifikasi pada visualisasi iklan wall painting yang di dominasi oleh produk dari operator telekomunikasi. Diantaranya; Telkomsel, XL, Indosat dan Axis. Karakter visual yang berbeda yang lebih sederhana dan hanya mengutamakan merek menunjukkan identifikasi visual yang jelas pada iklan tersebut.

Kata Kunci: Billboard, Media, Wall painting.

\section{PENDAHULUAN}

Iklan merupakan suatu bentuk komunikasi yang digunakan oleh pihak produsen kepada pihak konsumen. Iklan selalu menyertai pada setiap kehadiran suatu produk dan jasa, karena iklan menjadi salah satu ujung tombak pada kegiatan pemasaran. Sektor periklanan juga dapat memberi pendapatan pajak bagi pemerintah daerah dari suatu kota. Setiap iklan membutuhkan tempat dan ruang untuk dapat menjangkau audiennya, yang dikenal dengan nama 'media'. Perkembangan media saat ini sejalan dengan perkembangan komunikasi massa. Sebuah iklan dapat di tempatkan dimana pun bergantung dari audien yang ingin dituju. Media luar ruang memiliki target sasaran adalah masyarakat kota dengan 
tidak melihat faktor usia, tingkat pendidikan maupun status ekonomi. Iklan jenis ini bersifat sporadis karena media luar ruang bersifat terbuka dan mudah untuk dijangkau oleh setiap orang yang melintasi tempat titik iklan itu di tempatkan. Secara umum perkembangan iklan luar ruang senantiasa menggunakan media yang disebut 'billboard'. Perkembangan media tersebut mendominasi iklan luar ruang di tata ruang perkotaan dan di ruas jalan penghubung antar kota.

Produk-produk di pasaran yang umum memanfaatkan media 'billboard' sebagai alat promosi adalah; rokok, otomotif, telekomunikasi, makanan, minuman, juga properti. Kebutuhan masyarakat yang semakin beragam memberikan peluang bagi para produsen untuk memenuhinya dengan memberikan informasi terbaru tentang produknya. Produk telekomunikasi semakin berkembang, di tengah persaingan bisnis telekomunikasi yang ketat. Masing-masing perusahaan operator telekomunikasi gencar melakukan promosi melalui iklan. Strategi branding yang dilakukan diantaranya menggunakan media luar ruang wall painting.

Perkembangan periklanan melalui media luar ruang mengalami perubahan, ditandai dengan munculnya media yang memanfaatkan dinding rumah sebagai tempat beriklan, yang dinamakan dengan istilah 'wall painting'. Kemunculan iklan jenis ini menimbulkan pertanyaan pada dunia periklanan. Berdasarkan wujud visualisasi dan penerapan iklan di lapangan menunjukkan iklan ini memiliki sisi tradisional yang dalam proses pembuatannya menggunakan cat dinding secara manual. Namun secara content menyiratkan pesan dengan upaya penanaman brand pada benak konsumen. Untuk itu media ini dikatagorikan sebagai media non-tradisional. Perusahaan telekomunikasi yang menggunakan iklan tersebut adalah perusahaan seperti; Telkomsel, XL, Indosat, dan Axis.

Pertumbuhan iklan wall painting melalui pemanfaatan dinding rumah dan toko sebagai media branding menunjukkan perkembangan semakin bertambah meski jumlah penyebarannya tidak merata. Dinding yang digunakan adalah dinding rumah atau toko yang secara letak sangat strategis dan mengarah ke arah pejalan kaki atau pengendara yang melintas pada ruas jalan utama. Kondisi di lapangan 
memperlihatkan bahwa perusahaan operator telekomunikasi mendominasi iklan wall painting di beberapa kota besar.

Di dalam iklan wall painting umumnya warna korporat menjadi warna dominan pada sebuah dinding rumah yang digunakan. Seperti halnya Telkomsel yang memiliki warna merah, XL yang memiliki warna biru, Indosat menggunakan warna kuning dan Axis menggunakan warna ungu, yang semuanya sudah menjadi identitas yang terekam dalam benak masyarakat. Logo perusahaan atau merek dagang menjadi bagian point of view sebagai konten dari suatu iklan dinding bersama sloganpromosisebagai pelengkap.

Fenomena maraknya iklan wall painting menampilkan karakteristik visual iklan yang berbeda dari umumnya pada sebuah iklan luar ruang. Media ini dikatagorikan sebagai media non-tradisional yang merupakan bentuk media alternatif dengan tujuan sebagai attention dalam strategi iklan. Visualisasi wall painting yang berbeda ini di persepsi oleh masyarakat. Peneliti berusaha untuk mengetahui bagaimana visualisasi iklan ini dipersepsi oleh masyarakat sebagai target sasarannya.

\section{LANDASAN TEORI DAN METODE}

\subsection{Iklan}

Iklan atau "Advertising berasal dari bahasa Latin Advertere, artinya mengalihkan perhatian" menurut Santosa (2009:1), artinya sebuah reklame dibuat adalah untuk memberikan tanda agar diperhatikan oleh masyarakat. Iklan dibuat untuk mengkomunikasikan dan memberi perhatian kepada publik agar informasinya dapat disimak, diketahui dan diingat yang kemudian menjadi pertimbangan dalam pengambilan keputusan baik membeli atau menyimpannya sebagai suatu pilihan. Reklame atau iklan atau advertising, menurut Monle Lee dan Carla Johnson (2007:3) adalah:

Komunikasi komersil dan nonpersonal tentang sebuah organisasi dan produkproduknya yang ditransmisikan ke suatu khalayak target melalui media bersifat massal seperti televisi, radio, koran majalah, direct mail (pengeposan langsung), reklame luar ruang, atau kendaraan umum. 
Reklame atau iklan sering terlihat pada media-media publik yang banyak diakses oleh masyarakat. Iklan banyak menampilkan sesuatu hal yang positif sebagai bentuk promosi dari perusahaan. Iklan atau reklame telah mengalami berbagai perubahan dari berbagai zaman, hal ini karena iklan mampu melakukan penetrasi yang baik terhadap perkembangan teknologi media terkini. Menurut Frank Jefkins Istilah Periklanan merupakan pesan-pesan penjualan yang paling persuasif yang diarahkan kepada calon pembeli yang paling potensial atas produk barang atau jasa tertentu dengan biaya yang semurah-murahnya (Jefkins, 1997, p. 5).

Branding adalah cara pemasaran menciptakan makna khusus bagi suatu produk. Makna khusus atau brand image adalah hasil dari komunikasi dan pengalaman personal konsumen dengan suatu produk (Moriarty, Mitchell, \& Wells, 2011, p. 41).Branding membuat produk tampil beda dan unik di pasaran. Branding dapat mentransformasi produk. Sebuah brand dapat mewakili status, kualitas, atau nilai yang bagus. Merek atau brand saat ini sudah menjadi penentu keputusan membeli, dan orang rela antri berjam-jam demi sebuah produk yang memiliki brand terkenal. Intinya konsumen memiliki sudut pandang dan persepsi kuat terhadap suatu merek, sehingga kadang penilaian terhadap suatu produk cukup diwakili oleh merek apa yang terdapat pada produk tersebut. Brand atau merek sudah menjadi kekuatan dalam konsep pemasaran maupun sistem dalam strategi periklanan.

\subsection{Media}

Kita mengenal jenis media iklan seperti televisi, radio, papan reklame, surat kabar, majalah, poster, brosure, dan lain-lain. Para praktisi periklanan pada awalnya memandang bahwa "media periklanan dibagi menjadi dua jenis Above the Line dan Below the Line" menurut Sigit Santosa (2009:17). Namun saat ini hal itu tidak berlaku lagi karena masing-masing memiliki kekuatan dan kelemahan yang dapat saling melengkapi, "Untuk itu orang iklan memandang bahwa media reklame saat ini adalah Throught the Line Media". 
Media luar ruang disebut juga sebagai reklame luar rumah secara definisi dapat diuraikan oleh Monle Lee dan Carla Johnson (2007:284) "Media yang menjangkau orang-orang di luar rumah, ini termasuk periklanan luar ruang (misalnya papan reklame dan huruf lampu [signs]) dan periklanan sarana transit". Periklanan luar ruang merupakan media iklan pendukung yang merupakan bagian dari konsep utuh dari suatu kampanye.

Street furniture, meliputi; bus shelter, urban furniture, kiosk, convenience storedi dan shooping mall, stasiun bis, stasiun kereta api atau bandara (Suyanto, 2006). Iklan jenis ini lebih menempatkan pada media-media yang menjadi bagian pelengkap yang terdapat pada suatu kota. Transit, iklan yang terdapat pada taksi, bis, pesawat, kereta api, subway dan jenis kendaraan yang di kemas sesuai pesan iklannya. Alternatif Media, berupa tulisan di udara, balon, arena, stadion, bioskop, kampus, resort, atau kereta gantung (Suyanto, 2006).

\subsection{Desain Komunikasi Visual}

Desain komunikasi visual atau desain grafis merupakan keilmuan atau disiplin ilmu yang tidak mencakup eksplorasi visual, akan tetapi mencakup pula aspekaspek kultural, sosial, filosofis, teknis dan bisnis. Desain grafis harus terus berkembang dan menghadapi tantangan saat ini dari bahasa dan persepsi masyarakat menurut Peter Anderson dalam (Taschen, 2003). Desain komunikasi visual secara terapan memiliki empat fungsi dasar diantaranya: (Safanayong, 2006).

- to inform; untuk mengenalkan, menjelaskan, menerangkan.

- to enligten; untuk membuka pikiran dan menguraikan.

- to persuade; untuk memberikan aspek kepercayaan, logika dan daya tarik.

- to protect; untuk melindungi seperti kemasan.

Desain grafis adalah proses merancang gambar atau bentuk visual dwimatra untuk kepentingan proses komunikasi yang fungsional dan efektif. (Adityawan, Arief \& Concept Litbang, 2010) Dalam komunikasi visual terdapat pengolahan terhadap ide dalam proses kreasi, seleksi dan pengorganisasian terhadap elemen-elemen visual (Landa, 2011). Elemen-elemen visual yang digunakan dalam periklanan dan umumnya menjadi peralatan dalam mengolah suatu iklan visual yang 
dilakukan oleh seorang pengarah seni (Moriarty, Mitchell, \& Wells, 2011). Beberapa elemen visual dasar yang terdapat pada suatu objek visual diataranya; garis, bentuk (gambar, foto, tipografi, layout), warna, dan tekstur.

\section{OBJEK PENELITIAN}

\subsection{PT. Telekomunikasi Selular, Tbk.}

Telkomsel merupakan perusahaan operator telekomunikasi yang telah tumbuh dan berkembang pesat sejak berdirinya pada tahun 1995. Telkomsel memposisikan diri pada jasa pelayanan telekomunikasi selular melalui layanan suara maupun data. Telkomsel memberikan layanan kepada konsumennya dengan menambah jangkauan jaringan telekomunikasi ke seluruh wilayah Indonesia. Telkomsel pada saat ini menjadi pemimpin pasar selular di Indonesia, karena komitmennya untuk meningkatkan pelayanan dan inovasi teknologi komunikasi serta memperkuat pengelolaan keuangan perusahaan menjadi gerakan fundamental perusahaan.

Telkomsel dalam kegiatan promosi, bundling dan branding tetap memfokuskan pada layanan inti perusahaan yaitu; Kartu As dan Simpati. Kampanye promosi pada tahun 2010 dilakukan sangat agresif, karena kedua produk tersebut menjadi pemimpin pasar. Kampanye yang dikhususkan pada tarif murah sebagai pesan kuat komunikasinya. Kampanye ini terus berlanjut termasuk salah satunya melakukan langkah kampanye dengan menggunakan wall painting.

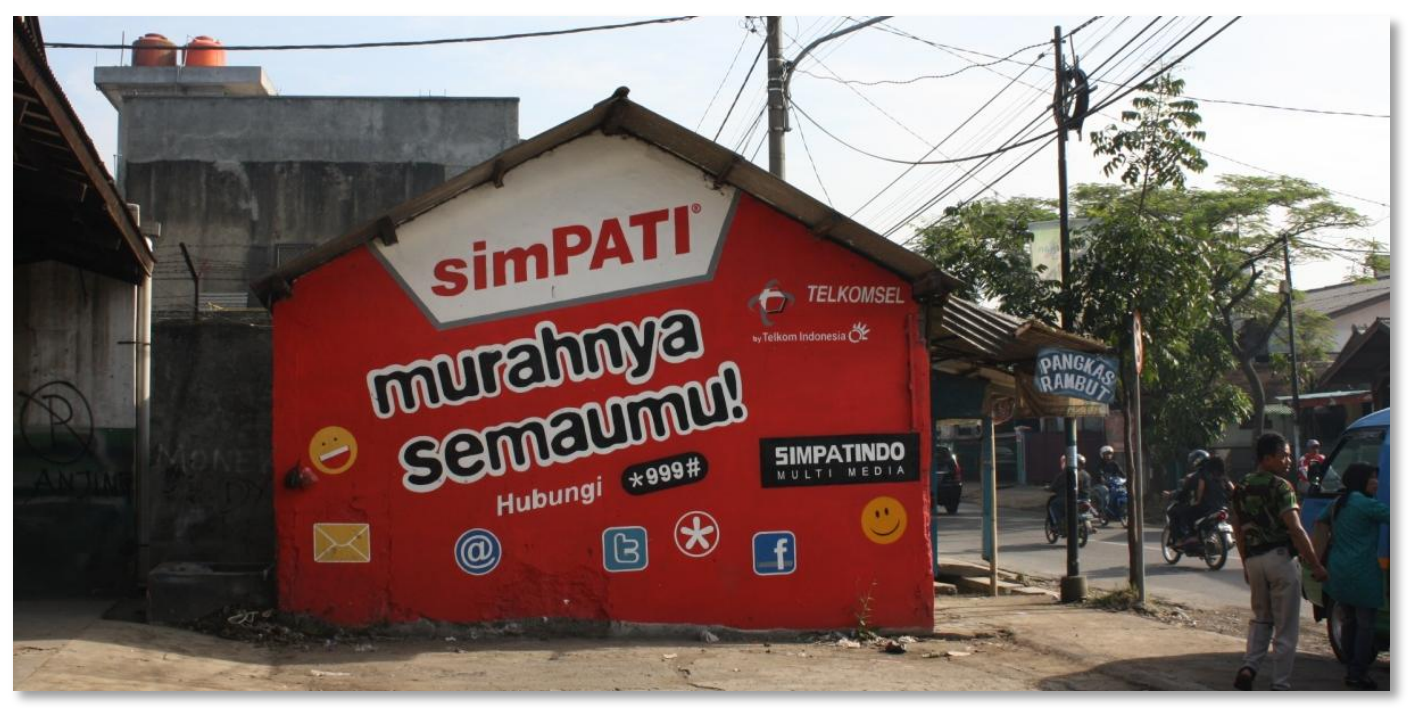

Gambar 3.5 iklan wall painting Telkomsel. (dokumen pribadi)

Program Studi Desain Komunikasi Visual, Universitas Komputer Indonesia 


\subsection{PT. XL Axiata, Tbk.}

Merupakan perusahaan penyedia layanan telekomunikasi yang agresif dalam memberikan pelayanan telekomunikasi berupa percakapan, sms, data dan pelayanan lainnya kepada masyarakat Indonesia. Salah satu dari beberapa kegiatan branding yang diambil XL untuk menciptakan visibilitas adalah dengan terus-menerus melakukan kegiatan branding permanen dengan melakukan pengecatan pada rumah, atap rumah, atau jembatan di daerah padat penduduk. Pada tahun 2011, XL telah mengecat atau wall painting hampir dua juta $\mathrm{m}^{2}$ tembok bangunan di 150 kota di Indonesia. (XL Axiata, 2012)

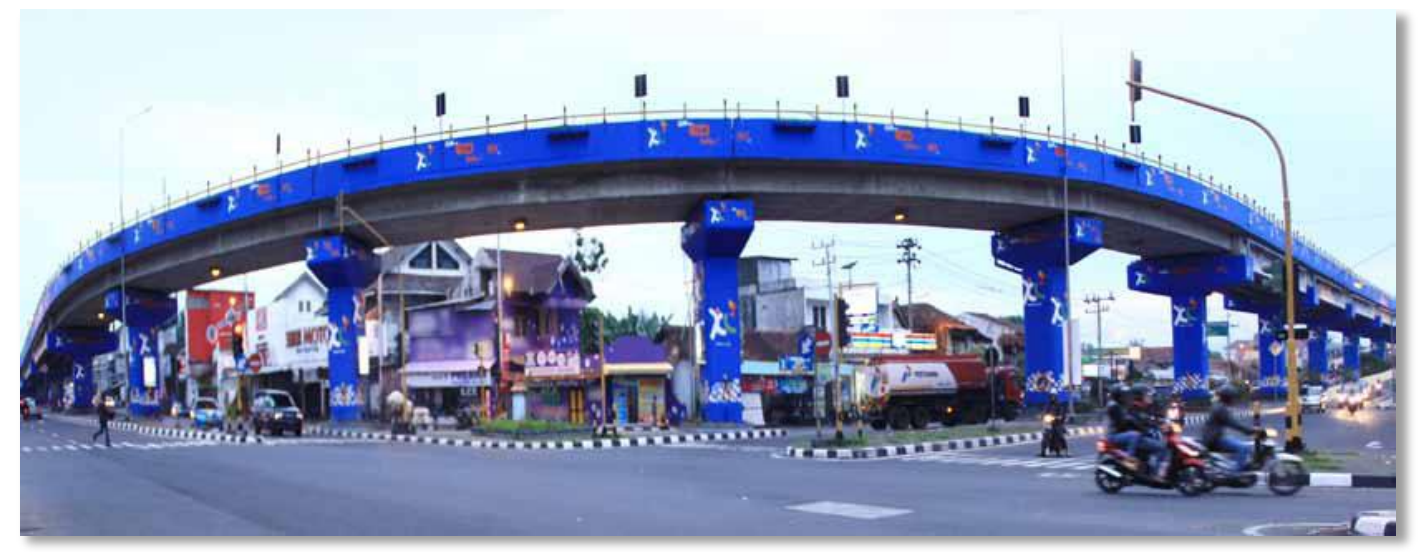

Gambar 3.7. Branding XL menjadi bagian pada elemen kota (XL Axiata, 2012)

\subsection{PT. Indosat, Tbk.}

Dalam program promosinya Indosat melakukan penjualan secara intensif melalui tenaga-tenaga penjual yang melakukan pendekatan kepada personal maupun korporasi-korporasi besar. Strategi marketing Indosat lebih memfokuskan kepada tarif yang flat, program bundling, menambah volume lalulintas komunikasi dari luar negeri ke Indonesia dan memperluas area sinyal Indosat di Indonesia. Indosat memperbaiki kampanye periklanan seperti menggunakan televisi, surat kabar, majalah, internet dan radio untuk memperbaiki kesadaraan terhadap brand. Indosat juga menggunakan wall painting sebagai media kampanye branding. 


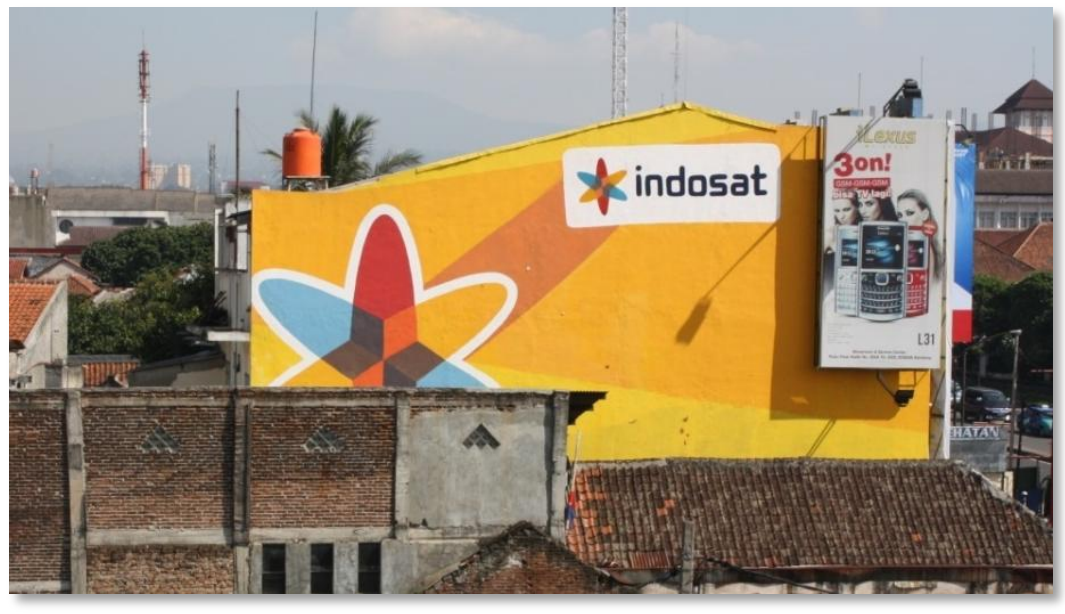

Gambar 3.9 Iklan wall painting Indosat (dokumen pribadi)

\subsection{PT. Axis}

Produk-produk Axis terhadap layanan komunikasi berfokus pada layanan selular suara dan sms, layanan data Internet, layanan budling Blackberry, dan layanan internasional. Promosi periklanan yang digunakan umumnya menggunakan media-media konvensional termasuk media nontradisional wall painting untuk melakukan penyebaran brand di Indonesia.

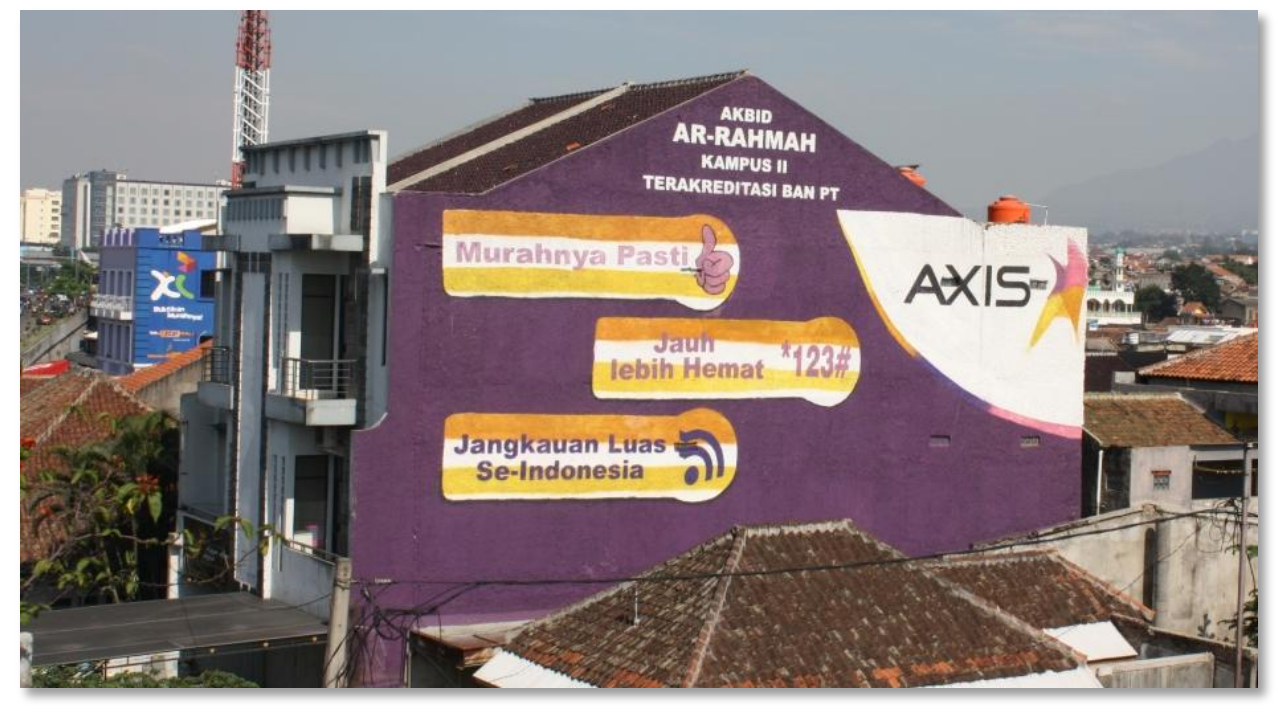

Gambar 3.11 PenerapanWall paintingbrand Axis (dok. Pribadi) 


\section{ANALISA}

\subsection{Analisa Identifikasi Visual Iklan Wall painting Produk Telkomsel}

Produk Telkomsel 'Kartu As' berdasarkan pengamatan lebih mengambil segmentasi pasar bagi masyarakat yang membutuhkan pelayanan telekomunikasi yang lebih murah dan terjangkau. Selain itu merupakan langkah untuk menghadapi bentuk persaingan harga terhadap produk operator telekomunikasi lainnya. Iklan wall painting 'Kartu As' umumnya berada bersamaan dengan iklan wall painting produk Simpati.

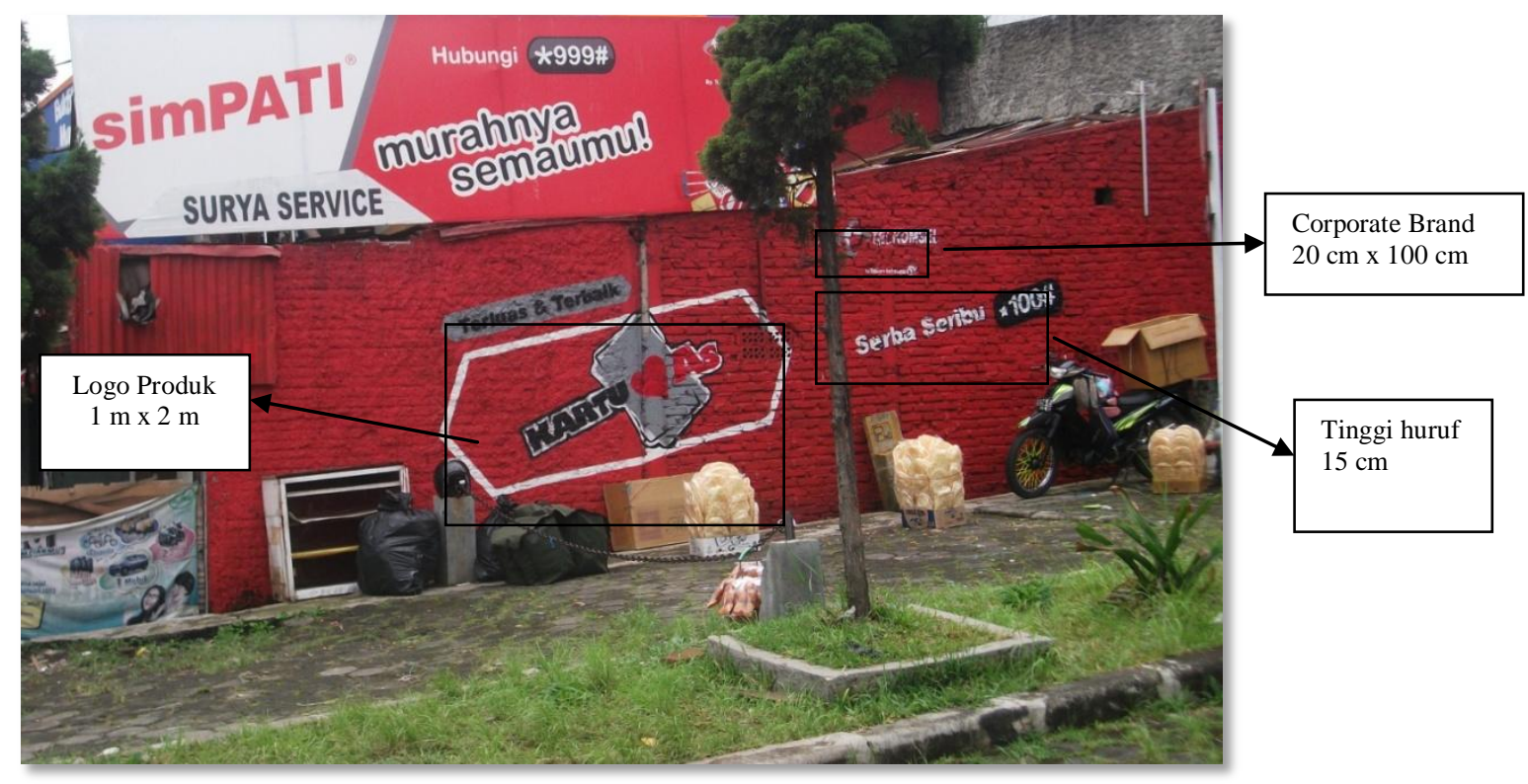

Gambar 4.15 Wall painting Kartu As 'Serba Seribu’ (dokumen pribadi)

Warna, merah menjadi warna tunggal yang menyatukan sistem grafis produkproduk Telkomsel, begitu juga dengan produk Kartu As. Meski berbeda karakteristik produk Telkomsel tetap mengikat produknya dengan warna-warna yang berasal dari warna korporasi. Warna sekunder yang dipakai adalah warna putih, abu dan hitam. Warna putih menjadi warna outline yang menjadi aksentuasi memberikan bentuk segi enam dan jargon Kartu As. Warna putih memberikan tingkat kontras, yang menjadikan pemisahan antara dua bidang secara jelas. Warna hitam berfungsi sebagai penguat yang memberi kesan kuat atau penekanan terhadap objek yang menjadi pusat perhatian dalam iklan wall painting ini. Warna abu hanya sebagai warna komplemen atau warna pelengkap yang berfungsi mengisi ruang yang menjadi bagian dalam sistem warna korporasi. 
Layout, penyusunan objek-objek pesan pada wall painting Kartu As menunjukkan fleksibelitas dalam penempatan objeknya. Akan tetapi tetap terdapat empat bagian yakni; warna dasar, bagian utama, bagian pesan atau jargon, dan nomor kontak layanan. Pada penyusunannya bagian utama ditempatkan pada rata tengah format wall painting. Menunjukan penanaman brand image pada benak khalayak terhadap produk Kartu As melalui branding.

Tipografi, terdapat dua jenis font sans serif yang digunakan pada wall painting dapat diklasifikasikan berdasarkan kemiripan jenis huruf. Kartu As ditulis menggunakan jenis huruf Arial Extra Bold yang di-extended, huruf jargon menggunakan huruf Arial bold atau Calibri bold. Jenis huruf yang digunakan memiliki kemiripan dengan huruf pada produk Simpati.

Gambar, logo gram merek produk secara visual menunjukan gambar kartu As Merah Hati, merupakan visualisasi dari produk Kartu As. Tumpukan kartu memperlihatkan adanya beberapa kartu yang berada dibawahnya. Framing terhadap logo adalah segi enam memanjang dengan outline besar untuk menguatkan pesan terhadap logo Kartu As. Bentuk segi enam diletakan dengan tingkat kemiringan tertentu, karakter ini mengikuti sistem grafis dari produkproduk Telkomsel. Kemiringan bentuk ini memberi kesan dinamis dan lebih memadukan elemen-elemen visualnya menjadi satu kesatuan yang lebih harmonis. Terdapat Logo Telkomsel berada disudut kanan atas sebagai ciri identitas korporat yang mengikat pada setiap produk perusahaan.

\subsection{Analisa Identifikasi Visual Wall painting iklan Operator Selular XL}




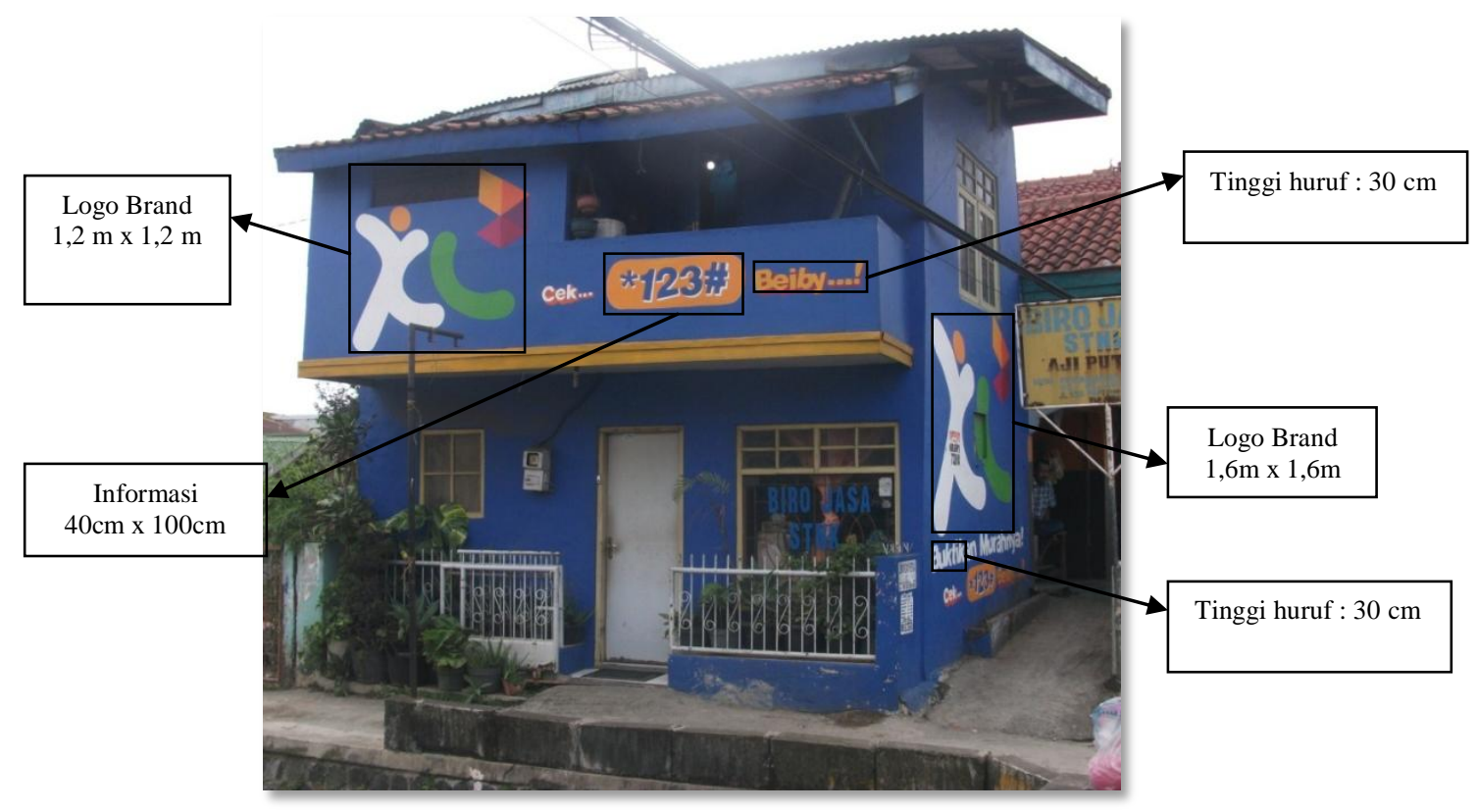

Gambar 4.16 Penerapan wall painting XL pada sebuah rumah (dokumen pribadi)

Identitas visual XL memiliki karakter yang khusus, perbedaannya terdapat pada beberapa elemen visual yang bisa langsung ditangkap oleh indera mata khalayak. Kekuatan visual yang sudah terbangun sejak awal melalui berbagai promosi perusahaan, dapat diteruskan dengan mudah melalui pendekatan media visual berupa wall painting. Keseragaman dalam elemen visual ini menjadikan XL tidak sulit dalam melakukan penerapan branding melalui berberapa aplikasi media. Pada penerapan iklan wall painting XL dilapangan khususnya di jalan Dr. Djunjunan memperlihatkan terjadinya suasana persaingan antar operator-operator telekomunikasi. Situasi seperti ini memungkinkan terjadinya 'perang pengaruh' diantara dua iklan operator selular yang saling berebut posisi peletakan wall painting pada wilayah operasi yang sama, seperti situasi dibawah ini. 


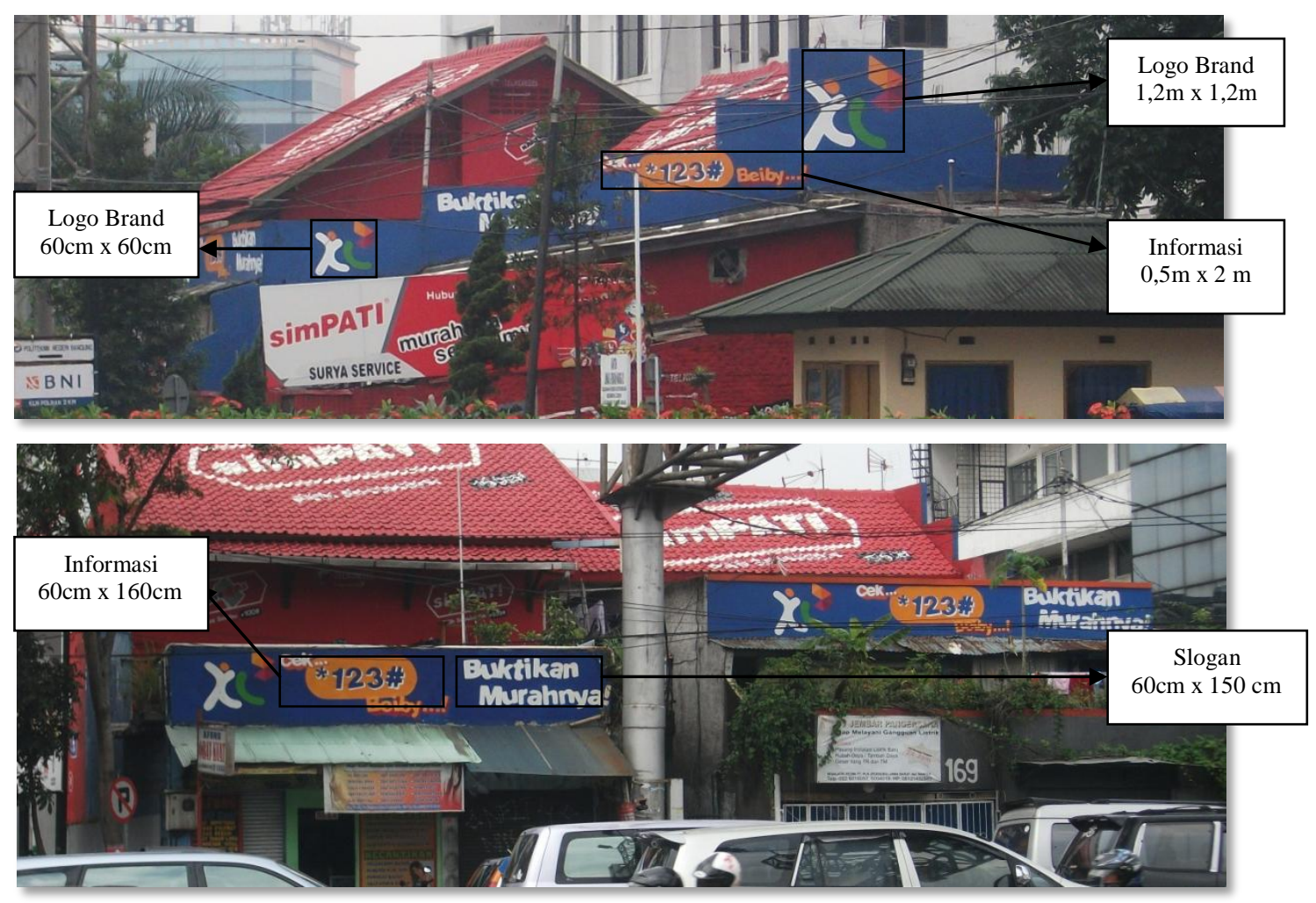

Gambar 4.17 Situasi 'persaingan' iklan dua operator pada wall painting (dokumen pribadi)

Warna, biru merupakan warna yang menjadi warna dasar produk 'XL' dan dapat dikatagorikan sebagai biru gelap dengan tingkat kekontrasan yang cukup kuat. Peneliti berusaha mencari informasi tentang jenis dan merek cat tembok kepada pihak yang terkait dan dihasilkan informasi bahwa 'XL' menggunakan jenis cat dari Mowilex Weathercoat dengan yang warna yang digunakan adalah warna Cyanine Blue BM 1009. Cat tembok jenis ini dirancang untuk mampu menghadapi perubahan cuaca diluar, karena $100 \%$ kandungannya adalah acrylic dan beberapa campuran yang dapat bertahan terhadap jamur dan lumut (mowilex.com, 2011). Warna biru memberikan kesan kontras yang cukup kuat sehingga membuat mata langsung tertuju pada objek, inilah yang diinginkan oleh 'XL' agar terjadi noise pada mata khalayak sehingga langsung memberi perhatian pada objek wall painting.

Warna, biru merupakan warna yang menjadi warna dasar produk 'XL' dan dapat dikatagorikan sebagai biru gelap dengan tingkat kekontrasan yang cukup kuat. Peneliti berusaha mencari informasi tentang jenis dan merek cat tembok kepada 
pihak yang terkait dan dihasilkan informasi bahwa ' $\mathrm{XL}$ ' menggunakan jenis cat dari Mowilex Weathercoat dengan yang warna yang digunakan adalah warna Cyanine Blue BM 1009. Cat tembok jenis ini dirancang untuk mampu menghadapi perubahan cuaca diluar, karena $100 \%$ kandungannya adalah acrylic dan beberapa campuran yang dapat bertahan terhadap jamur dan lumut (mowilex.com, 2011). Warna biru memberikan kesan kontras yang cukup kuat sehingga membuat mata langsung tertuju pada objek, inilah yang diinginkan oleh 'XL' agar terjadi noise pada mata khalayak sehingga langsung memberi perhatian pada objek wall painting.

Layout, penempatan elemen-elemen visual XL pada dinding rumah, toko atau suatu bangunan menyesuaikan dengan bentuk dan luas dari suatu bangunan yang dindingnya akan di-wall painting-kan. Bagian utama dari suatu iklan XL adalah logo yang merupakan identitas yang telah dikenal oleh khalayak. Identitas ini telah dibangun sejak lahirnya produk XL tersebut. Bagian pelengkap yang terdiri dari jargon dan layanan informasi, adalah elemen visual penyerta yang selalu ada apabila pada penempatannya memungkinkan.

Bagian utama selalu ditempatkan pada bagian center atau posisi dimana dapat menjadi fokus perhatian dari suatu bidang wall painting. Diharapkan mata khalayak langsung tertuju pada logo XL yang memberikan sensasi pikiran untuk selalu mengingat atau remainding terhadap produk XL. Logo XL pada proporsinya yang simetris, apabila ditarik garis bantu maka tinggi dan lebarnya sama sisi. Bentuk logo secara geometris berbentuk bujur sangkar ini memungkinkan untuk dapat ditempatkan secara lebih mudah, baik pada bidang vertikal maupun horizontal. Juga memungkinkan untuk dapat dilakukan pengulangan, sehingga dalam suatu bidang terdapat lebih dari satu logo XL, bergantung dari bidang bangunan yang digunakan sebagai landasan pengecetan wall painting.

Jargon atau Slogan produk ditempatkan secara horizontal disesuaikan dengan rangkaian tulisan yang terdiri dari dua buah kata sejajar. Penempatan jargon ini 
lebih melihat bidang yang tersedia dan pada prinsipnya memiliki skala yang lebih kecil dibandingkan dengan logo XL. Penempatan jargon pada umumnya diletakan dibawah logo, namun bidang yang tidak tetap (unformating) pada wall painting membuat penempatannya tidak lagi beraturan. Jargon dapat ditempatkan pada kiri, kanan, atas atau bawah dari logo XL, dengan tidak memiliki format visual standar yang diterapkan pada semua wall painting.

Satu elemen visual lain yang dikuatkan pada iklan wall painting XL, adalah nomor layanan XL “cek *123\# Beiby..!". Kode nomor ini kadang dibesarkan sejajar dengan penempatan yang berdampingan dengan logo. Kode layanan ini memiliki kekuatan yang sama dengan jargon, sehingga pada kondisi tertentu peneliti menemukan elemen visual wall painting yang hanya terdapat logo dan kode layanan tanpa adanya jargon. Kode layanan ini berisikan program promosi, pelayanan informasi dan berbagai layanan telekomunikasi yang ditawarkan secara suara kepada pelanggannya.

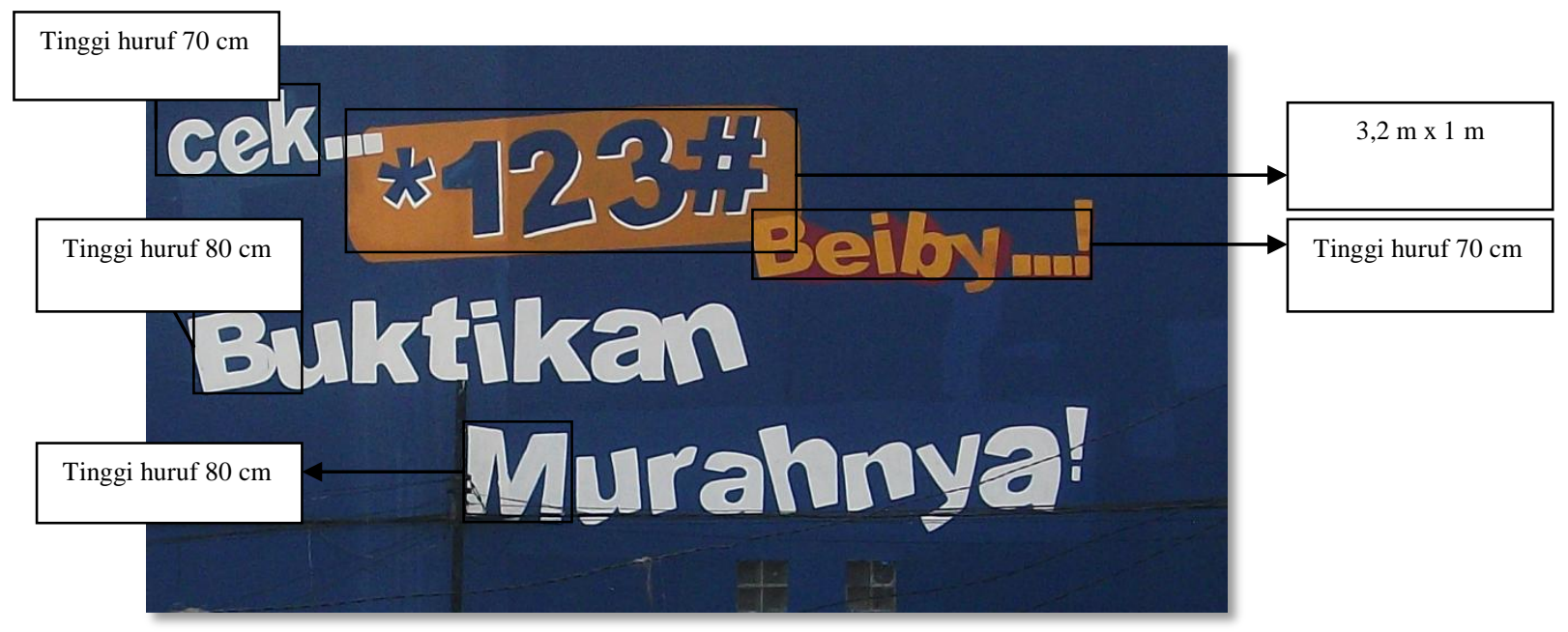

Gambar 4.20 Tipografi pada wall painting 'XL' (dokumen pribadi)

Tipografi, penggunaan huruf dan cara penulisan pada iklan XL, seperti pada jargon XL; "Buktikan Murahnya.!", menggunakan huruf yang berjenis sans serif dengan keluarga huruf yang tebal atau bold. Penggunaan huruf kecil dengan kapital di depan kata, bertujuan agar terlihat penekanannya terhadap jargon XL.Ketidakteraturan penyusunan huruf yang tidak terdapat pada satu garis lurus untuk menjauhkan kesan formalisasi atau kekakuan pesan. Tingkat kerning yang 
kecil menjadikan jarak antar huruf seakan berdesakan namun tetap memiliki tingkat keterbacaan yang cukup baik. Huruf tersebut tersusun agar dapat menyatu atau blending dengan lingkungannya, sebagaimana huruf vernacular yang mampu merekam dinamika masyarakat di jalan. Selain jargon terdapat pesan-pesan verbal lainnya yang memiliki jenis huruf dan cara penulisan yang serupa seperti pada penulisan jargon.

\subsection{Analisa Identifikasi Visual Wall painting iklan Operator Selular Indosat}

Indosat melakukan pendekatan iklan melalui media wall painting melalui pendekatan yang paling sederhana dibandingkan operator lainnya. Penetrasi Indosat berjalan bertahap dan menyebar diwilayah kota Bandung secara sporadis, terutama di wilayah strategis. Akan tetapi kehadiran wall painting Indosat tidak segencar pesaing besarnya Telkomsel dan XL. Pendekatan yang dilakukan masih berupa pendekatan brand, dan ada beberapa melalui pendekatan produk dan secara konsepsi visual memiliki kemiripan dengan operator lainnya. Peneliti menguraikan beberapa indentifikasi visual dan merupakan bagian dari strategi yang terdapat pada wall painting Indosat.

Warna, kuning terangpada Indosat berasal dari warna dasar korporasi, yang terdapat pada website resmi Indosat. Warna tersebut merupakan warna pengikat sistem grafis visual promosi Indosat. Warna komplementer lainnya adalah warna putih yang berfungsi untuk menutupi warna dasar untuk penempatan brand Indosat. Penambahan warna lainnya berasal dari warna identitas brand Indosat dengan warna-warna biru, orange, merah, dan warna hasil irisan antar bagian geometris sehingga menghasilkan warna tumpukan yang lebih gelap. Outline dari logo gram korporasi ini adalah warna putih untuk lebih menonjolkan visualisasi logo Indosat. Pada strategi visual ini Indosat menggunakan contrastvalue dari ruang publik dengan melakukan pendekatan warna kuning yang menyolok perhatian. Hal ini dikaitkan dengan strategi pembeda atau differensiasi antarproduk lain dan memberikan suatu tanda dari sisi pelanggan akan kebutuhan eksistensi terhadap suatu pelayanan. Warna dasar kuning Indosat ini terdapat gradiensi yang dikombinasi dengan warna orange yang menjadi dasar wall painting. 


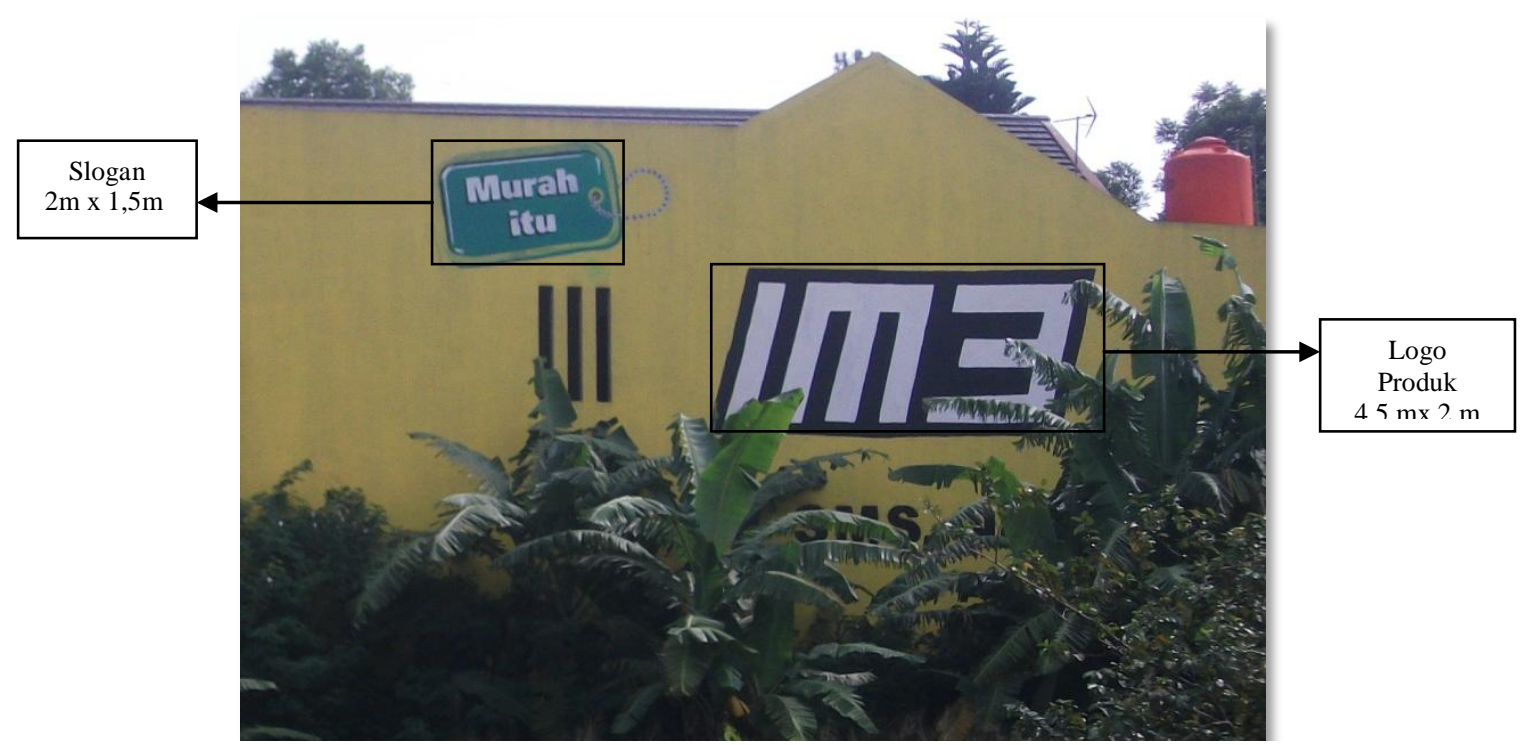

Gambar 4.22 IM3 produk Indosat pada wall painting (dokumen pribadi)

Pada produk IM3 warna yang digunakan adalah warna hitam dan hijau, dengan kombinasi warna dengan dasar kuning. Warna hitam digunakan untuk merek produk IM3, sebagai salah satu produk andalan Indosat yang menjangkau masyarakat luas. Tagline produk berupa pesan 'murah itu' ditulis dengan warna putih diatas modul warna hijau dalam bangun persegi empat bersudut tumpul menunjukan penguatan pesan. Hijau meski bukan termasuk dalam warna korporasi Indosat namun merupakan bagian dari warna produk Indosat, selain hijau juga merupakan warna turunan dari warna kuning. Komposisi warna ini masih merupakan bagian dalam sistem grafis visual Indosat.

Layout, posisi dan penempatan memperlihatkan suatu bentuk yang berbeda dengan kompetitor-kompetitor lainnya. Perbedaannya terletak dari segi penempatan logo korporasi yang terletak umumnya terpotong oleh bidang wall painting. Branding dicukupkan oleh warna yang kuning Indosat dengan kontras yang mem-blending seluruh area dinding. Terpotongnya logo tidak merubah atau merusak dari corporate image dari Indosat, akan tetapi merupakan bagian darielemen visual dari suatu komposisi desain. Penempatan logo tersebut umumnya ditempatkan disebelah kanan bawah dari area wall painting. Beberapa bagian umumnya terpotong namun terdapat pula bagian logo yang utuh sehingga terlihat sebagai satu komposisi yang lengkap. 
Produk Indosat IM3 memperlihatkan komposisi yang berdiri sendiri, sehingga tidak terdapat logo dan brand Indosat pada wall painting IM3. Logo IM3 diletakan di tengah dengan skala disesuaikan dengan area dinding, tab hijau sebagai dasar warna untuk tagline. Komposisi yang sederhana ini memperlihatkan bahwa Indosat tidak menguatkan brand pada setiap produk dengan logonya, tetapi melepas produk IM3 untuk mampu berdiri sendiri dan hanya colourbrand yang menjadi pengikat sistem grafisnya. Warna isi huruf putih diatas dengan garis luar hitam bertujuan untuk lebih memberikan tekanan terhadap produk IM3 agar menjadi perhatian utama.

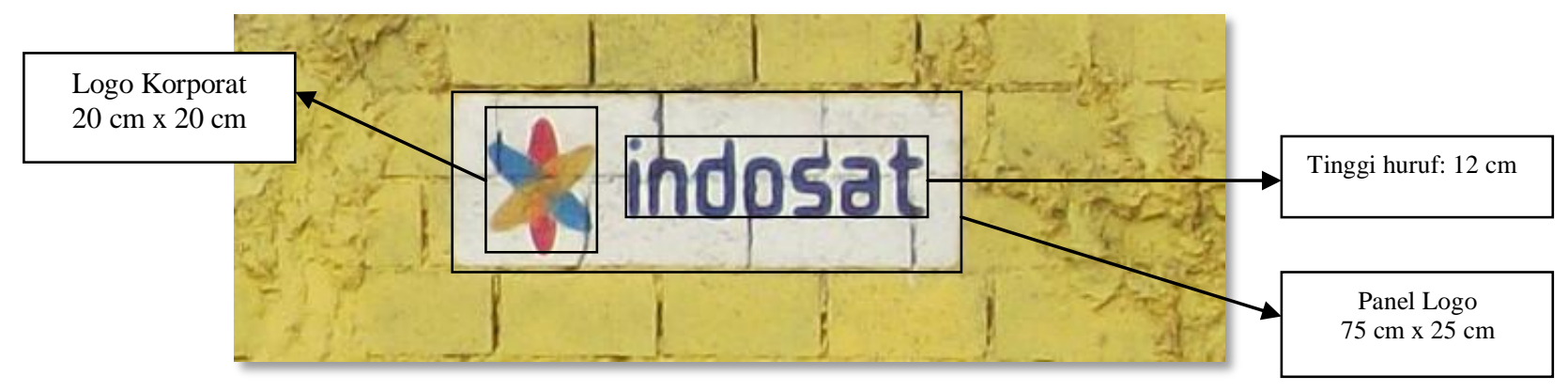

Gambar 4.24 Tipografi Indosat pada wall painting (dokumen pribadi)

Tipografi, pada Indosat sangat minim dan hanya untuk memperkuat brand-nya Indosat, dengan jenis huruf sans serif seperti yang digunakan pada brand corporate-nya. Jenis huruf merupakan huruf identitas korporat dari Indosat dengan kerning positif sehingga jarak antar hurufnya tampak renggang. Jarak ini untuk mempermudah pengidentifikasian, karena memungkinkan mata untuk menangkap identitas objek lebih cepat.

Tipografi yang digunakan oleh produk IM3, menunjukan dinamisasi dan berkarakter modern future, dengan mengadopsi jenis sans serif dengan huruf kecil. Wujud karakter dinamis dan future terlihat dari kemiringan huruf dan kesederhanaan huruf yang merujuk bentuk geometris dan huruf bersudut tajam. Family huruf yang teranalisa merupakan jenis bold sehingga menambah aksen tebal pada huruf. Pada tagline iklan jenis huruf menunjukan penguatan terhadap pesan melalui bayangan huruf dan dengan permukaan berwarna putih. Illusi optik juga dipakai dengan memberi bayangan huruf agar lebih terlihat keluar. Jenis dan 
karakter huruf yang digunakan tidak sama dengan huruf pada logo produk melainkan menggunakan sans serif dengan jenis huruf Arial Bold tipe lower case.

Gambar, lebih terfokus kepada bentuk logo korporat berupa bangun geometrik tiga buah lingkaran oval yang saling bertumpuk dan bertumpu pada satu titik poros. Pertemuan masing-masing bangun menghasilkan warna dan bidang yang baru dengan garis luar tebal untuk memisahkan dengan latar belakang objek. Pada produk IM3 gambar difokuskan pada bentuk persegi empat bersudut tumpul yang menjadi latar belakang pada tagline objek. Gambar lebih divisualisasikan sebagai sebuah tab nama yang dilengkapi dengan rantai gantung, tujuannya adalah untuk memberi kesan sebuah gantungan. Gambar dibuat dengan gaya illustrasi sederhana sebagai penggambaran dari bentuk aslinya. Pada wall painting gambar tidak dapat seperti bentuk nyata atau photo seperti pada media billboard, gambar harus mengalami penyederhanaan bentuk dan warna dengan tidak mengurangi pesan visual yang ingin dicapai.

\subsection{Analisa Identifikasi Visual Wall painting iklan Axis}

Axis merupakan perusahaan operator selular yang paling muda umurnya, namun Axis telah memiliki jaringan dan pelanggan yang cukup besar. Pada perkembangannya Axis harus bersaing dengan perusahaan-perusahaan yang sudah terlebih dahulu mengenal pasar telekomunikasi di Indonesia. Dalam promosi pelayanannya Axis berusaha mencari pelanggan-pelanggan baru juga untuk menambah kesetiaan pada pelanggan yang telah ada.

Dalam kegiatan promosinya, Axis menawarkan berbagai paket promosi diantaranya; melalui program paket hemat dan program paket gratis, baik nelpon, sms, dan internet. Hal ini menjadikan setiap iklan promosinya selalui terdapat paket program-program tersebut, termasuk dalam penyampaian pada iklan wall painting. Disini penulis berusaha mengurai dari sisi visual iklan wall painting Axis, melalui beberapa unsur dibawah pada elemen visual diantaranya adalah;

Warna, ungu adalah warna dasar yang digunakan axis sebagai warna pengikat sistem visual grafis pada wall painting. Warna ini merupakan warna brand image yang dimiliki oleh Axis. Warna ini terdapat didalam logo Axis yang merupakan 
logo terbuka dan bersifat abstrak. Logo Axis merupakan logo yang tidak umum, karena dari segi bentuknya memperlihatkan bentuk yang tidak beraturan, dan dari sisi warna memiliki spektrum warna dari ungu, magenta sampai orange. Warna ungu memiliki tingkat kekontrasan dan menjadi pembeda yang baik diantara warna-warna dari operator lainnya. Warna ungu ini merupakan identitas Axis yang telah dikenal sejak awal kehadirannya, melalui berbagai program promosi yang baik iklan televisi maupun billboard dan poster. Warna ungu didampingi oleh warna putih, sebagai bentuk komposisi yang selalu ada karena logo Axis harus ditempatkan pada dasar putih.

Warna lainnya adalah adalah warna orange, magenta dan kuning, yang menjadi aksentuasi terhadap komposisi wall painting pada iklan Axis. Warna-warna ini berasal dari warna pada logo Axis, sehingga dapat dimanfaatkan menjadi kombinasi bidang pada komposisi wall painting. Strategi visualnya adalah agar iklan wall painting memiliki sistem grafis yang sama pada promosi produknya.

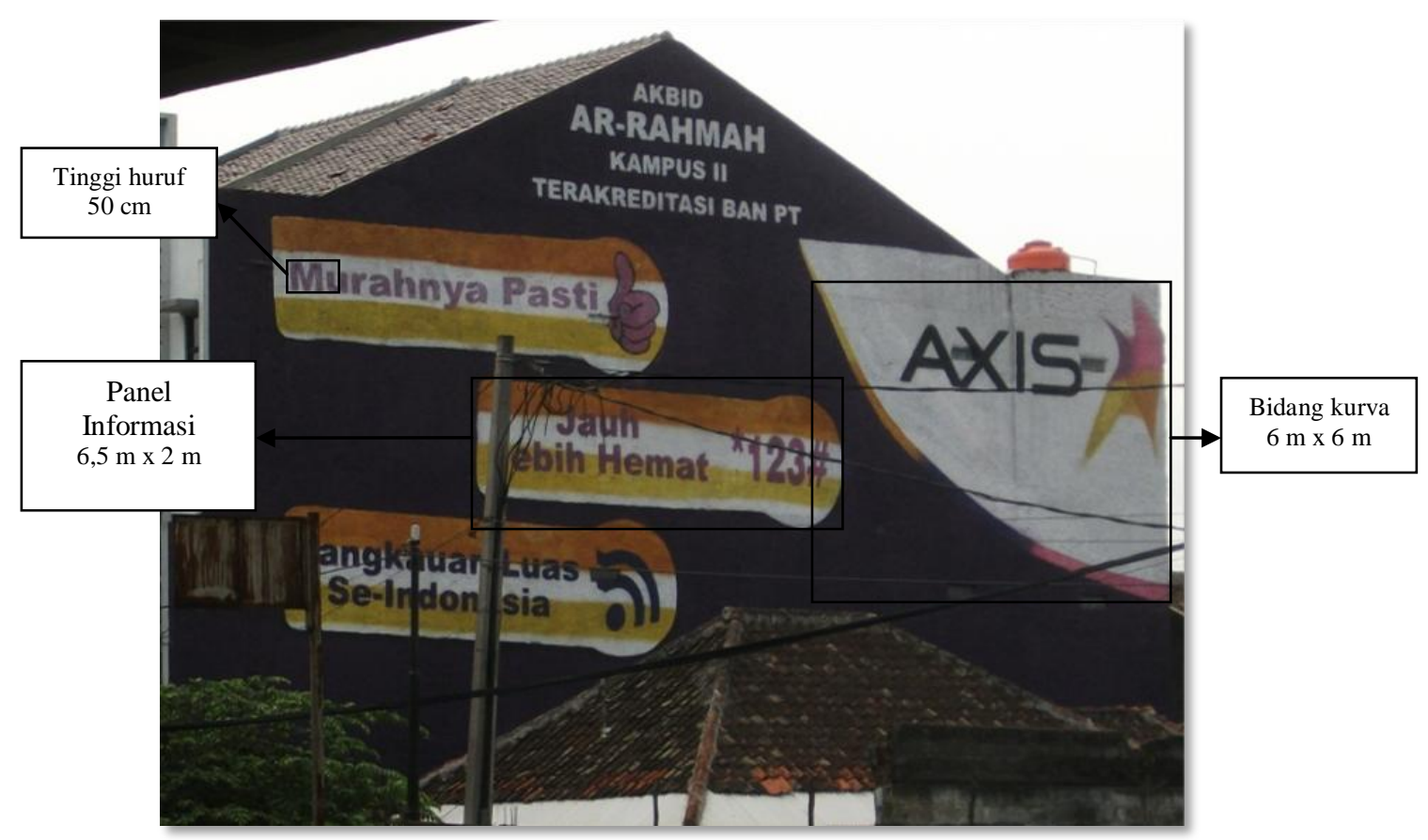

Gambar 4.27 layout Axis pada wall painting (dokumen pribadi)

Layout, tata letak pada komposisi wall painting Axis memperlihatkan bentuk komposisi yang kompleks, karena sistem grafis pada Axis melibatkan berbagai informasi promosi kedalam wall painting. Logo Axis umumnya ditempatkan pada 
sudut kanan atas pada bidang dinding, ditempatkan diatas latar belakang warna putih. Terdapat dua jenis bentuk layout yang digunakan oleh operator Axis dalam penelitian ini yaitu; layout baru dan layout lama. Keduanya memuat pesan yang sama namun berbeda pada tatanan grafisnya. Pada layout baru memperlihatkan bentuk kurva besar yang memisahkan bidang logo dan bidang informasi. Bidang informasi lebih memuat informasi dengan bentuk tiga buah kapsul yang tersusun pada bidang dasar ungu. Sementara pada layout lama menunjukan empat buah persegi empat tumpul yang tersusun dengan berisi muatan informasi yang sama, namun pada informasi nomor pelayanan terpisah tersendiri.

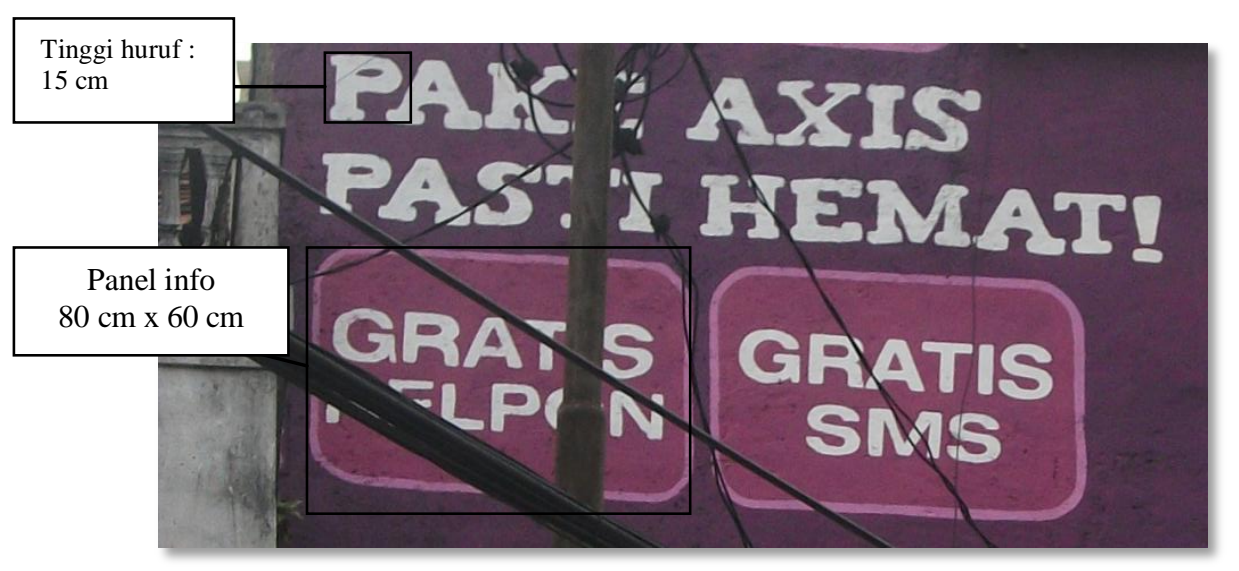

Gambar 4.29 Tipografi iklan Axis pada wall painting (dokumen pribadi)

Tipografi, huruf yang digunakan umumnya menggunakan huruf sans serif dengan jenis family huruf bold, informasi promo yang digunakan Axis menggunakan jenis huruf berdasarkan asumsi peneliti melihat sifat kemiripan bentuk merupakan termasuk Arial bold. Menggunakan jenis huruf kecil dengan jarak antar huruf yang renggang memperlihatkan agar lebih mudah dibaca. Aksara merek Axis tetap seperti pada branding yang terdapat pada logo korporatnya. Merupakan huruf sans serif jenis light yang berjenis huruf besar keseluruhan. Huruf pada tagline hanya terdapat pada jenis iklan lama Axis. Jenis hurufnya merupakan huruf serif yang menyerupai jenis huruf Slub serif atau serif yang ditebalkan.

Gambar, elemen visual berupa gambar pada iklan Axis sangat dominan dijumpai, dari bentuk logo hingga tab konten iklan. Bentuk logo merupakan visualisasi yang rumit agar mempertahankan konsistensi dalam pengaplikasian pada semua media. 
Bentuk logo terbuka ini menjadikan cara pengerjaannya menggunakan cara pengecatan manual. Gambar lain berupa ikon-ikon pendukung menunjukan lambang dari berbagai layanan Axis. Gambar acungan jempol menunjukan murahnya produk Axis yang terjangkau oleh khalayak. Nomor layanan *123\# dijadikan pelayanan secara customer service untuk memudahkan penjelasan terhadap informasi produk Axis. Gambar ikon sinyal menunjukan daya jangkau Axis yang dapat menjangkau wilayah Indonesia. Gambar Paneltulisan berupa bentuk geometris sederhana berupa kapsul dan persegi empat tumpul yang membatasi dengan latar belakang wall painting.

\section{PENUTUP}

\subsection{Kesimpulan}

Wall painting merupakan media luar ruang baru yang digolongkan kedalam media non-tradisional. Media ini berperan membantu dalam pembangunan citra suatu brand juga memperkuat citra brand yang telah ada di mata para pelanggannya. Wall painting memberi dampak pengingatan kembali terhadap pengalaman khalayak terhadap produk yang digunakannya, sehingga menstimuli untuk mempertahankan dan tetap loyal pada produk tersebut. Rumah atau bangunan di sisi jalan merupakan bagian dari ruang publik yang selalu terlihat oleh pengelihatan pengendara atau para pengguna jalan raya.

Identifikasi visual pada wall painting, memperlihatkan kesederhanaan dan kemudahan visual dari sisi teknis maupun bentuk visualnya. Pesan, slogan atau jargon umumnya dibuat sangat lugas dengan tipografi yang sederhana agar huruf dapat terbaca cepat dan pesan dapat langsung ditangkap audien. Informasi call center merupakan data tambahan yang diperlukan agar audien memiliki tempat bertanya mengenai informasi detail dan promosi yang dilakukan oleh masingmasing operator. Simbol-simbol visual lainnya hanya melengkapi ruang visual wall painting.

Warna merupakan unsur visual yang paling mudah dikenali oleh khalayak. Dari empat operator telekomunikasi seluruhnya direspon sama oleh khalayak dengan 
warna sebagai point of view pada iklan wall painting. Warna juga mengandung pesan sebagai warna korporasi yang mencitrakan budaya perusahaan. Warna bersifat universal namun setelah mendapat elemen visual lain seperti logo perusahaan maka yang tampak lebih pada sosok perusahaan atau produk yang ditampilkannya.

Branding sangat membentuk citra sebagai pengalaman khalayak akan suatu produk. Sehingga munculnya visualisasi branding yang berada ditengah ruang publik menimbulkan pendekatan emosi yang pada konsumennya. Wall painting dikatakan sebagai wujud branding perusahaan terhadap produk yang diproduksinya. Perusahaan telekomunikasi sebagai produsen menggunakan iklan wall painting dengan harapan dapat mempererat hubungan dengan konsumennya. Konsepsi branding dalam wall painting terlihat dari muatan informasi yang terkandung di dalamnya. Pesan yang ditampilakan jauh lebih sedikit dibanding media-media promosi lainnya. Muatannya hanyalah sebagai penguat atau reminding terhadap produk yang telah dipakainya.

Publik masyarakat menangkap wall painting sebagai suatu bentuk komunikasi alternatif dari pihak produsen pada mereka sebagai pelanggan. Strategi visual wall painting lebih mengarahkan audien kedalam bentuk asosiasi yang bersifat emosional terhadap brand yang telah matang atau brand yang memiliki keinginan untuk melawan kekuatan-kekuatan yang sudah ada. Strategi visual tersebut menggunakan warna dan brand sebagai reminder yang terus menerus distimulasikan pada benak audien. Strategi ini bersifat soft sell sehingga yang dituju adalah benak khalayak agar terjadi pembangun identitas brand yang berujung kepada loyalitas terhadap brand.

\subsection{Saran}

Publik merasa tidak terganggu dengan bermunculannya wall painting dalam ruang publik kota, sebagian masyarakat memandang sebagai bentuk alternatif iklan yang memberi dampak positif terhadap estetika kota. Namun pengaturan wall painting juga diperlukan agar tidak terjadi penumpukan iklan pada suatu tempat yang mengakibatkan dampak negatif. Wall painting sebaiknya lebih memperhatikan 
ruang tempat dipakainya yang berkaitan dengan ekosistem kota. Sekolah atau fasilitas sosial lainya sebaiknya tidak terdapat unsur iklan wall painting. Atau mungkin wall painting dapat berkembang menjadi penambah unsur estetika kota dengan menggabungkan dengan mural positif, sehingga terjadi keseimbangan pada ekosistem kota.

\section{DAFTAR PUSTAKA}

Adityawan, Arief \& Concept Litbang. (2010). Tinjauan Desain Grafis. Jakarta: Concept media.

Alma, B. (2008). Metode dan Teknik Menyusun Tesis. Bandung: Alfabeta.

Altstiel, T., \& Jean, G. (2007). Advertising Strategy. Thousand oaks, California: Sage Publication Inc.

Arntson, A. E. (2007). Graphic Design Basics, Fifth Edition. Belmont, CA 94002-3098: Clark Baxter.

Atmoko, P. (2008). Identifikasi tampilan visual media Billboard dalam ruang publik kota. Bandung: Institut Teknologi Bandung.

Baudrillard, J. (2004). Masyarakat Konsumsi. Yogyakarta: Kreasi Wacana Yogyakarta.

Bradley, S. (2011, February 7). design layout. Dipetik September 21, 2012, dari Vanseo design: http://www.vanseodesign.com

Budiman, K. (2011). Semiotika Visual. Yogyakarta: Jalasutra.

Dharmaprawira, S. (2002). Warna, teori dan kreativitas penggunaanya. Bandung: Penerbit ITB.

Fakultas Ilmu Komputer, Universitas Indonesia. (2008). Dipetik Agustus 26, 2012, dari Kamus Besar Bahasa Indonesia: http://bahasa.cs.ui.ac.id

Fidler, R. (2003). Mediamorfosis. Yogyakarta: Bentang Budaya.

Follis, J., \& Hammer, D. (2008). Dalam P. Atmoko, Identifikasi Tampilan Visual Media Billboard.

Follis, J., \& Hammer, D. (1979). Architectural, Signing and Graphics. New York: Whitney Library of Design.

Forrester, M. (2002). Psychology of the image. Canada: Routledge.

Gobe, M. (2003). Emotional Branding. New York: ALLWORTH press. 
Jefkins, f. (1997). Periklanan. jakarta: Erlangga.

Kasali, R. (1992). Manajemen Periklanan. Jakarta: Pustaka Utama Grafiti.

Kusmiati, A., \& Suptandar, P. (1997). Unsur Warna dalam Perancangan Desain. Jakarta: Universitas Trisakti.

Landa, R. (2011). Graphic Design Solution. Boston: Wadsworth.

Lee, M., \& Johnson, C. (2007). Prinsip-prinsip pokok periklanan dalam perspektif global. Jakarta: Prenada Media Group.

Masri, A. (2010). Strategi Visual. Yogyakarta: Jalasutra.

Moriarty, S., Mitchell, N., \& Wells, W. (2011). ADVERTISING. jakarta: kencana.

Purwanto, D. (2006). komunikasi Bisnis. Jakarta: Erlangga.

Safanayong, Y. (2006). Desain komunikasi visual terpadu. jakarta: Buana Print.

Shimp, T. A. (2003). Advertising \& Promotion Supplemental Aspect of Integrated Marketing Communication 2nd. Jakarta: Erlangga.

Singarimbun, M., \& Effendy, S. (2011). Metode Penelitian Survei. Jakarta: LP3ES.

Shimp, T. A. (2003). Advertising Promotion and Supplemental Aspect of Integrated Marketing Communication. Jakarta: Erlangga.

Sihombing, D. (2001). Tipografi dalam Desain Grafis. jakarta: Gramedia.

Suhandang, K. (2005). Periklanan: Manajemen, Kiat dan Strategi. Bandugn: Nuansa.

Sutopo, H. (2006). Metodologi Penelitian Kualitatif. Solo: Universitas Sebelas Maret.

Sukma W, B. (2011). Ambient Media. Jakarta: BSW printing.

Susanto, H. (2009). Proposal Tepat Bisnis Melesat. Jakarta: Visimedia.

Suyanto, M. (2007). Marketing Strategi Top Brand Indonesia. Yogyakarta: Andi.

Suyanto, M. (2006). Strategi Perancangan Iklan Outdoor Kelas Dunia. Yogyakarta: Penerbit Andi.

Taschen. (2003). Graphic Design to 21 st Century. Cologne: Taschen Gmbh.

Walker, J. A. (2010). Desain, Sejarah, Budaya. Yogyakarta: Jalasutra.

Withbread, D. (2001). The Design Manual . Sydney: UNSWpress. 